\title{
Assessment of the tidal current energy resource in São Marcos Bay, Brazil
}

\author{
Eduardo González-Gorbeña ${ }^{1}$ - Paulo C. C. Rosman $^{1} \cdot \operatorname{Raad}$ Y. Qassim ${ }^{1}$
}

Received: 4 December 2014 / Accepted: 26 May 2015 / Published online: 17 June 2015

(C) Springer International Publishing AG 2015

\begin{abstract}
At the present time, the role of renewable energy in Brazil is significant as hydropower and other renewable energies, principally biomass, contribute 76.9 and $6.0 \%$, respectively, towards the total offer of electricity, as compared to the corresponding values of 15.8 and $2.8 \%$ worldwide. Nevertheless, there is already an increasing role which is played by wind energy, and a promising potential for the exploitation of tidal current energy. This paper is concerned with the assessment of the tidal current resource in São Marcos Bay, which is located at the northeastern coast of Brazil, and which possesses a highly promising potential for the generation of electricity through the conversion of tidal current energy. Three potential zones for tidal power exploitation have been identified employing a two-dimensional (2DH) hydrodynamic model. Power densities for these regions are in the range of $9.2-11.2 \mathrm{MWh} / \mathrm{m}^{2}$-year. Three array densities for two thrust coefficient values have been studied in each zone to evaluate hydrodynamic interferences, revealing positive as well as negative impacts regarding power density.
\end{abstract}

Keywords Tidal current energy - Marine hydrokinetic . Resource assessment · Power density · São Marcos Bay

Eduardo González-Gorbeña

eduardogg@oceanica.ufrj.br

Paulo C. C. Rosman

pccrosman@ufrj.br

Raad Y. Qassim

qassim@peno.coppe.ufrj.br

1 Department of Ocean Engineering, Federal University of Rio de Janeiro / The Alberto Luiz Coimbra Institute for Graduate Studies and Research in Engineering (COPPE), Centro de Tecnologia, Bloco C, sala 203, Cidade Universitaria, Ilha do Fundao, Rio de Janeiro CEP 21945-970, Brazil

\section{Introduction}

Ocean waters cover more than $70 \%$ of the earth's surface and constitute a promising potential for renewable energy resources, out of which tidal stream energy capacity could exceed 120 GW globally (Marine Current Turbines 2012). As is the case with wind energy, tidal current energy is highly site sensitive. As a result, site selection assumes a critical role in the assessment of the techno-economic feasibility of the conversion of tidal current energy for the purpose of commercial electricity generation. In fact, site selection is necessarily the first step in any such assessment, as indeed is the case in wind energy. A detailed overview of the history, physics, and technology of tidal current energy extraction may be encountered in Hardisty (2009). The techno-economic feasibility of tidal current energy extraction for the purpose of commercial electrical power production depends on two major aspects: tidal current energy available at a given geographical site and tidal current turbine technology cost (Qassim 2011). Several studies have been reported on geographical sites in various parts of the world, with a view to the assessment of the potential for tidal current energy extraction; see, for example, Bryden et al. (2007), Grabble et al. (2009), Rourke et al. (2010), Lim and Koh (2010), Brooks (2011), Define et al. (2011), Liu et al. (2011), Rashid (2012), Adcock et al. (2013), Blunden et al. (2013), and Chen et al. (2013). Tidal current turbine technology has progressed at an increasing pace in the past couple of decades (Qassim 2011; Fraenkel 2010). The prospect for tidal current energy extraction for commercial-scale electrical power production depends to a large extent on generation cost, as measured by the levelised cost of energy; for a review of electricity generation cost assessment for fossil and renewable energy sources, the interested reader is referred to Kammen and Pacca (2004). Various aspects of the economics of tidal current energy extraction 
costs are treated in Denny (2009), Allan et al. (2011) and Li et al. (2011).

Pereira et al. (2012) provide a recent overview of the renewable energy market in Brazil, including hydro power, wind energy, solar energy, bioethanol, and biodiesel; however, tidal current energy is not considered. It is precisely the objective of this paper to make a start in filling this gap, on the potential of tidal current energy extraction in promising geographical sites in Brazil, by the presentation of an assessment of the tidal current energy resource at São Marcos Bay, a highly promising site on the northeastern coast of Brazil, which is part of the South Atlantic Continental Shelf.

Once a given geographical site is identified as promising for the generation of electrical power through the conversion of tidal current kinetic energy, a resource assessment at the aforementioned site needs to be carried out. In this context, it is necessary to distinguish between two energy quantities that are associated with the site under consideration: available energy and extractable energy. Available energy is obtained from a knowledge of the magnitude of the fluid kinetic energy in the absence of Tidal Energy Converters (TEC); i.e., turbines. Extractable energy is determined by the magnitude of the fluid kinetic energy harvested by TEC. A concise summary of this distinction is provided in Adcock and Draper (2014).
The paper is organised as follows: in Sect. 2, an overall description of São Marcos Bay is presented. This is followed in Sect. 3 by introducing the objectives of the present work. In Sect. 4 the main necessary conditions for efficient power extraction are defined. In Sect. 5, the hydrodynamic model embedded in the software SisBaHiA ${ }^{\circledR}$ is described. Numerical results obtained by application of SisBaHiA ${ }^{\circledR}$ to São Marcos Bay are presented in Sect. 6. The paper is concluded in Sect. 7 by presenting conclusions and recommendations for future work related to tidal currents exploration in São Marcos Bay.

\section{São Marcos Bay description}

The coastline of Brazil has an extension of approximately $8000 \mathrm{~km}$. Tides are semidiurnal and mixed-semidiurnal at the northern and southern halves of the coast, respectively. Macro-tidal ( $>4 \mathrm{~m}$ ) conditions are found in the Amazon coast which includes the States of Amapá, Pará and Maranhão. São Marcos Bay, located at the State of Maranhão (Fig. 1), has a tidal range that can reach more than $8 \mathrm{~m}$ in some zones during equinoctial spring tides. As tidal power generation depends strongly on tidal current velocities which, in turn, are closely related to tidal ranges, this region is interesting for study.

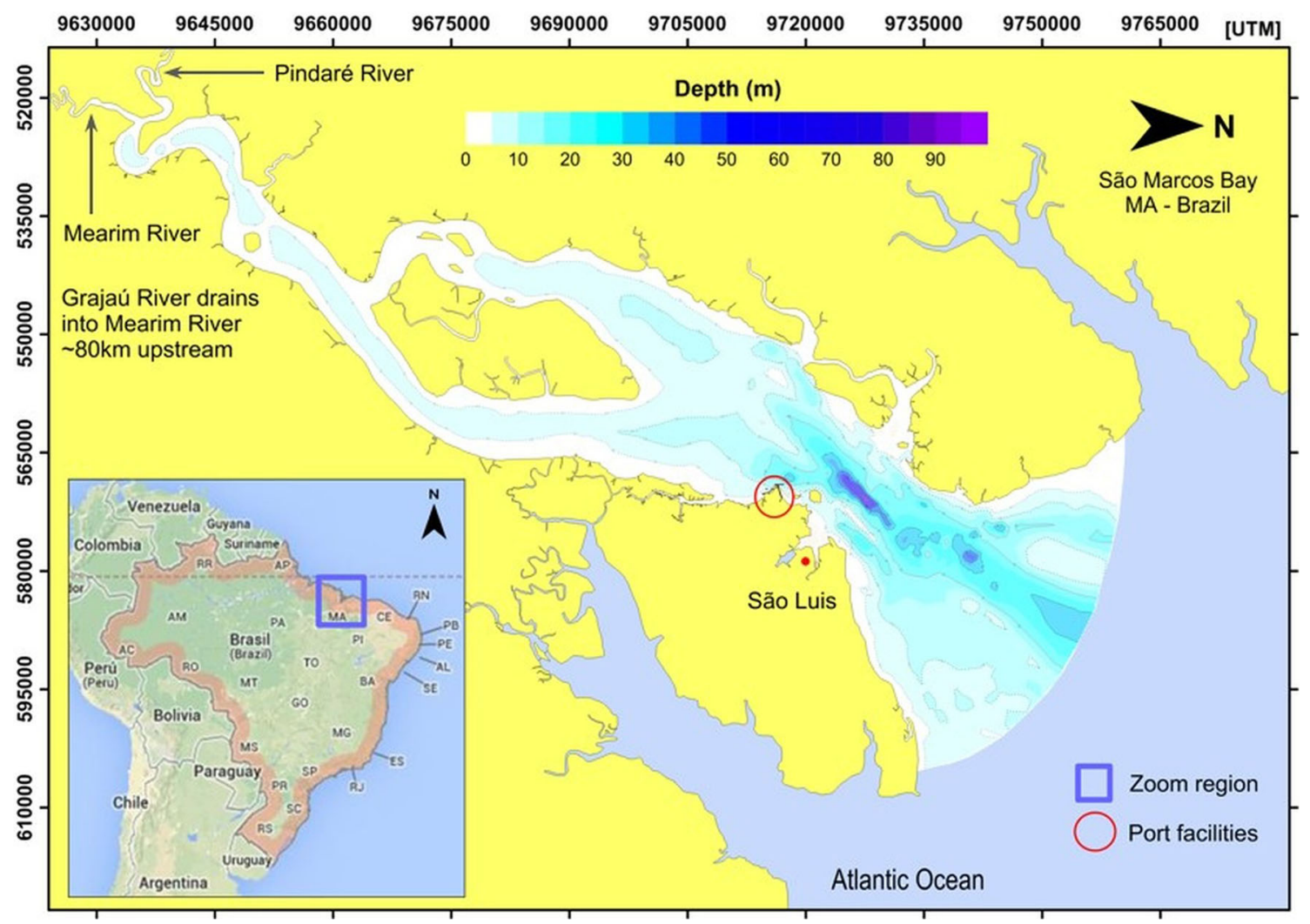

Fig. 1 Location map of São Marcos Bay-MA, Brazil 
São Marcos Bay together with São José Bay forms the geologic unit known as the Maranhense Gulf which encloses estuaries, straits, inlets, small rivers, and many islands, as well as large mangrove areas, and tidal flats (El-Robrini et al. 2006). A large mangrove island, named Ilha do Caranguejo, lies in the southern half of the Bay, resulting in two channels running along both sides. The three main rivers of the watershed are the Pindaré, Mearim, and Grajú, whose waters discharge at the southernmost region of the Bay and are responsible for the suspended solid loads, primarily clay and silt, with annual average values of $\sim 250 \mathrm{mg} / \mathrm{L}$ (Malheiro da Silva 2011). The entrance of the Bay has a width of $\sim 55 \mathrm{~km}$, which narrows to $\sim 15 \mathrm{~km}$ in its central section, widening again to $25 \mathrm{~km}$ before reaching Ilha do Caranguejo, and then continuously decreasing to $1.5 \mathrm{~km}$ at the intersection of Pindaré and Mearim rivers (Malheiro da Silva 2011). The Bay has a very well-defined central channel, with depths up to 97 m (Marinha do Brasil 1999a), and serves as a waterway for the main port facilities: Porto de São Luis, Porto de Itaqui, Ponta da Madeira terminal, and Alumar terminal. Ponta da Madeira terminal is undergoing an expansion to increase its export capacity to 235 millions of tons per year of iron mineral, becoming the port with the largest volume of cargo in Brazil. In addition to ore export, the region has steel and aluminium mills, such facilities representing the major driving force of the region. These facilities are highly intensive electrical energy consumers, which augurs well for its promise for tidal current energy extraction, as the need for transmission systems is eliminated.

\section{Objectives}

The first objective of this paper is to assess the potential of the tidal current resource in this region in terms of power density. The power density per square meter available from the kinetic energy of a tidal stream is given by

$P=\frac{1}{2} \rho U_{o}^{3}$

where $\rho$ is the reference fluid density and $U_{o}$ is the vertical averaged free stream velocity. Due to the fact that power is a function of the cube of the velocity, small alterations of quantity will result in significant changes in available power density.

At the present time and for the past few years, one of the main lines of research on marine hydrokinetic energy has been related to array layout optimisation, c.f., (Bryden and Couch 2007; Garrett and Cummins 2008; Thomson 2011; Vennell 2012a, b; Funke et al. 2014; Gorbeña et al. 2015). As the work that is reported in this paper is a prelude to a more detailed study of turbine positioning within São Marcos
Bay, the second objective of this paper is to analyse the effect on tidal free stream at a specific region caused by the presence of turbine arrays located in one or more other regions. Once promising zones have been identified, this objective is achieved by modelling different TEC density scenarios. The general purpose of this study is to reveal the necessity of a layout optimisation model for farm sizing and positioning within the Bay to avoid possible interferences between arrays in different zones.

\section{Main necessary conditions for efficient power extraction}

According to information available in the literature (Fraenkel 2002, 2007; Myers and Bahaj 2005), the necessary hydrodynamic and hydraulic conditions for efficient power extraction via TEC, may be su mmarised as follows:

1. Median current velocities greater than $1.1 \mathrm{~m} / \mathrm{s}$ are economically suitable for energy extraction. Ideal velocities are those for locations with mean spring peak tidal currents in the range of $2-2.5 \mathrm{~m} / \mathrm{s}$, or $4-5$ knots.

2. Depths between 20 and $50 \mathrm{~m}$ for first generation tidal turbine technology are adequate. In this case, consider that the usable segment of the water column, $z$, stays between $0.25 z$ above the Bay bottom and $3 \mathrm{~m}$ below the MLWS, mean low water springs, in harbour areas, or $7 \mathrm{~m}$ below MLWS in open coastal areas vulnerable to high wind waves.

3. Areas with tidal current field that reverses along a defined axial direction are more suitable for turbine installations than regions with currents without preferable direction.

4. Even though seabed composition directly affects foundation design, it is not taken into account in this paper. In this study, a fixed bottom is assumed, which means that turbine arrays do not affect bathymetry contours. Sea bed erosion is an issue to be considered in a subsequent study.

In a future investigation, environmental, use-conflict and commercial feasibility constraints should be considered to identify appropriate zones and quantify power yield amounts where TEC could be installed.

\section{SisBaHiA ${ }^{\circledR}$ hydrodynamic model}

In order to cope with the complex geometry of the domains of interest, and with the necessity of using refined discretisation within regions of interest, a finite element open access modelling system has been adopted, which is $\mathrm{SisBaHiA}^{\circledR}$, which is the acronym for Base System for Environmental Hydrodynamics in Portuguese. This modelling system is in essence similar and comparable to other well-known circulation mod- 
els like MIKE 21, POM, DELFT 3D, and TELEMAC. The motivation for using SisBaHiA ${ }^{\circledR}$ as the modelling system is twofold: (1) its adequacy to represent well the desired fluid flow processes in water bodies with complex geometry, ensuring a high-quality modelling; and (2) the fact that it is an open source code, with regular updating at COPPE/UFRJ since 1987.

The site http://www.sisbahia.coppe.ufrj.br provides ample information about $\mathrm{SisBaHiA}^{\circledR}$. The reliability of the SisBaHiA ${ }^{\circledR}$ system can be inferred by the long list of projects in which it has been applied in the past 10 years; see the item "Aplicações-Projetos" in the site. Complete technical details about the models are in Rosman (2014). For convenience, a brief description of the hydrodynamic model is presented in the next subsection.

\subsection{Further details of SisBaHiA ${ }^{\circledR}$ hydrodynamic model}

The SisBaHiA ${ }^{\circledR}$ hydrodynamic model is a 3D or $2 \mathrm{DH}$ (vertical averaged) model optimised for environmental hydrodynamics with hydrostatic and Boussinesq approximations. Calibration processes are minimised using spatial discretisation via quadratic finite elements and the $\sigma$ transformation. This ensures the possibility of obtaining detailed results for water bodies with complex coastal lines and bathymetries. Surface and bottom stresses can vary dynamically in time and space. Turbulence is modelled using a multiscale approach. Horizontal sub grid scale turbulent stresses are based on filtering techniques, similar to the ones adopted in the Large Eddy Simulation (LES) procedure. Small scale horizontal and vertical turbulent stresses employ the eddy viscosity approach. The eddy viscosity tensor is anisotropic and is dynamically variable in space and time for each node. Baroclinic effects can be included in the hydrodinamic modelling by coupling transport models of active scalars like salinity and/or temperature. Also, it can include a morphological evolution model coupled with a sediment transport model.

Considering that Sao Marcos Bay is a vertically wellmixed estuary, the vertically averaged-2DH model of SisBaHiA ${ }^{\circledR}$ suffices. Basically, the model employed in this work is an evolution of the one used in Rosman (2009) with an added stress term. The basic governing equations, in simplified versions, follow. For full 2DH and 3D versions of the equations, see Rosman (2014).

Continuity equation:

$\frac{\partial \zeta}{\partial t}+\frac{\partial}{\partial x_{i}}\left[\hat{u}_{i}(\zeta+h)\right]=0, \quad i=1,2$,

where $z=\zeta(x, y, t)$ stands for the free surface elevation, $z=$ $-h(x, y, t)$ for the bottom bathymetry, and $\hat{u}_{i}$, for the depth averaged velocity in the $i$-th direction. In models with fixed bathymetry, $h$ is time-independent.

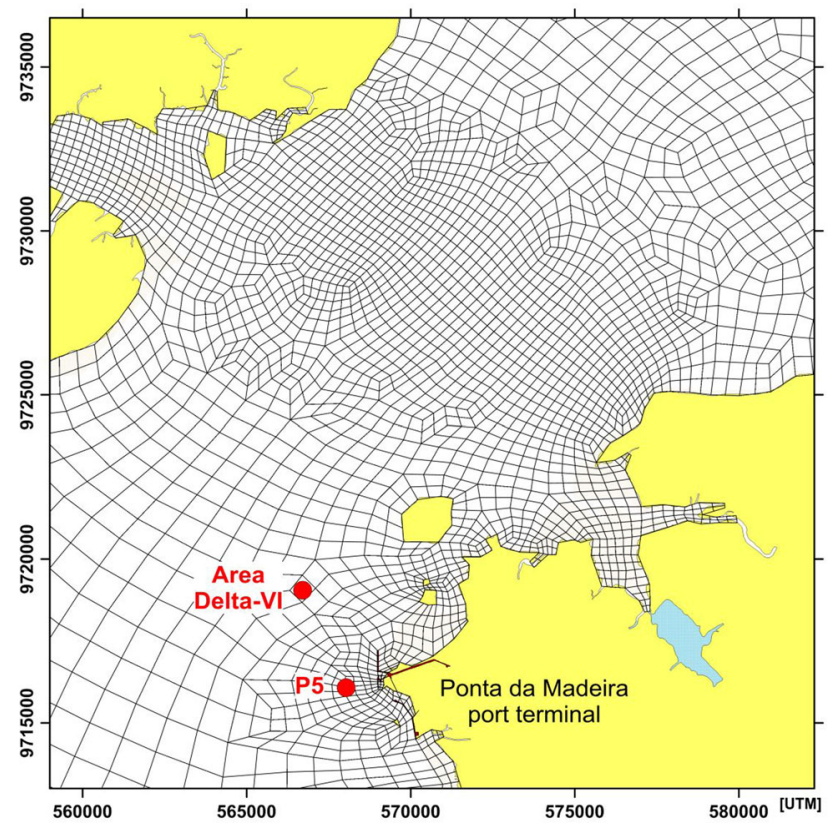

Fig. 2 Portion of the computational grid for the São Marcos Bay hydrodynamic modelling

Table 1 Maximum and minimum monthly average flow discharges for the main rivers in the region

\begin{tabular}{lllc}
\hline \multirow{2}{*}{ River } & Gauge station & \multicolumn{2}{c}{ Monthly average discharge, $\mathrm{m}^{3} / \mathrm{s}$} \\
\cline { 3 - 4 } & & Minimum & Maximum \\
\hline Mearim & Barra do Corda & 45.2 & 97.0 \\
& Bacabal & 50.6 & 199.0 \\
Grajaú & Grajaú & 9.2 & 86.7 \\
& Arati-Grande & 15.2 & 317.0 \\
Pindaré & Pindaré-Mirim & 27.6 & 532.0 \\
\hline
\end{tabular}

Conservation of linear momentum equation:

$$
\begin{aligned}
& \frac{\partial \hat{u}_{i}}{\partial t}+\hat{u}_{j} \frac{\partial \hat{u}_{i}}{\partial x_{j}}=-g \frac{\partial \zeta}{\partial x_{i}}+\frac{1}{\rho} \frac{1}{H} \\
& \quad \times\left[\begin{array}{c}
\frac{1}{\partial x_{i}}\left(\begin{array}{c}
H \hat{\tau}_{i j}^{T} \\
1 *
\end{array}\right)+\tau_{i}^{S}+\tau_{i}^{B}+\tau_{i}^{T} \\
2 *
\end{array}\right]+\hat{a}_{i}, \quad i, j=1,2
\end{aligned}
$$

Here $H=\zeta+h$ stands for the local water column height, $\hat{a}_{i}$ represents the Coriolis acceleration term, $1^{*}$ are depthaveraged turbulent shear stresses, $2^{*}$ and $3^{*}$ stand for shear stresses in the $i$-th direction and at the free surface and at the bottom, respectively. Finally, $4^{*}$ stands for the turbine stress term added to account for the head losses due to the influence of TEC. The turbine stress term is expressed as

$$
\tau_{i}^{T}=\frac{1}{2} \rho C_{\mathrm{T}}\left(\hat{u}^{2}+\hat{v}^{2}\right)^{0.5} \hat{u}_{i} \cdot \Theta, \quad i=1,2,
$$


Table 2 Tidal constituents measured in Ponta da Madeira gauge located at port facilities shown in Fig. 1

\begin{tabular}{llllcl}
\hline Constituent & Amplitude $(\mathrm{cm})$ & Phase $\left(^{\circ}\right)$ & Constituent & Amplitude $(\mathrm{cm})$ & Phase $\left(^{\circ}\right)$ \\
\hline Q1 & 1.7 & 192 & M2 & 211.6 & 199 \\
O1 & 9.3 & 211 & L2 & 13.1 & 203 \\
M1 & 1.2 & 214 & T2 & 3.9 & 229 \\
P1 & 3.1 & 238 & S2 & 57.8 & 235 \\
K1 & 9.9 & 240 & K2 & 16.1 & 229 \\
J1 & 0.5 & 282 & MO3 & 1.2 & 324 \\
MNS2 & 3.3 & 261 & M3 & 2.0 & 313 \\
2N2 & 7.9 & 191 & MK3 & 0.7 & 026 \\
MU2 & 9.5 & 291 & MN4 & 1.5 & 177 \\
N2 & 38.6 & 186 & M4 & 5.0 & 183 \\
NU2 & 10.2 & 172 & SN4 & 0.6 & 114 \\
\hline
\end{tabular}

P5

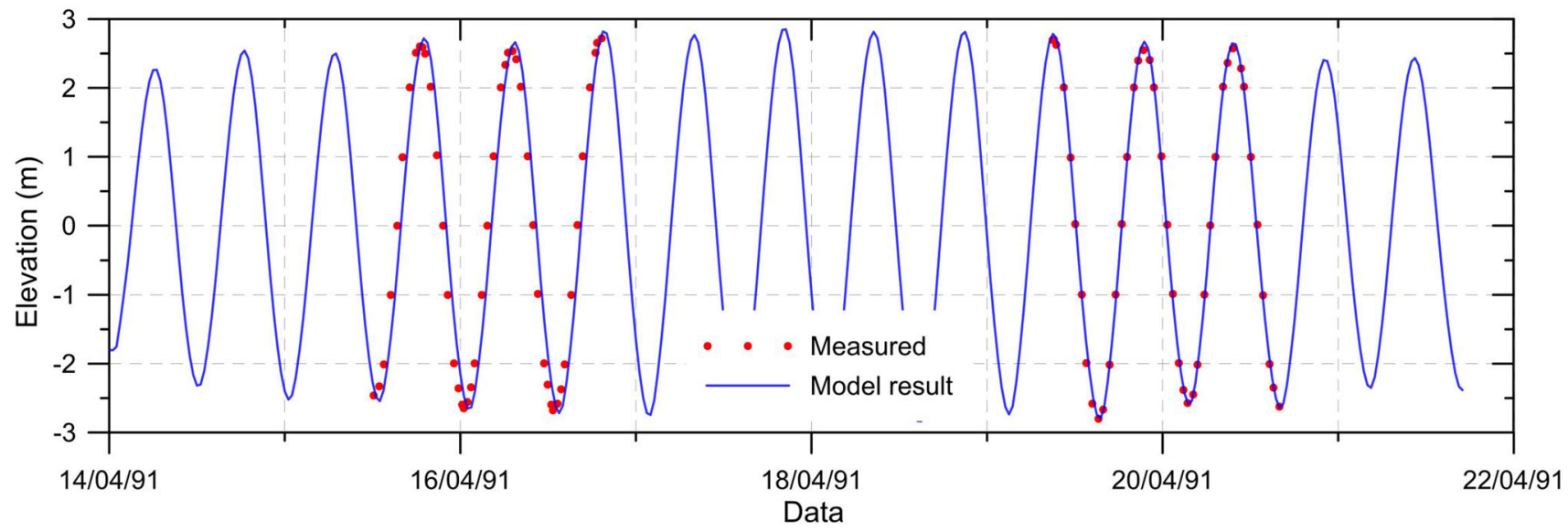

Fig. 3 Comparison between measured and computed water surface elevation (without mean water level) at P5

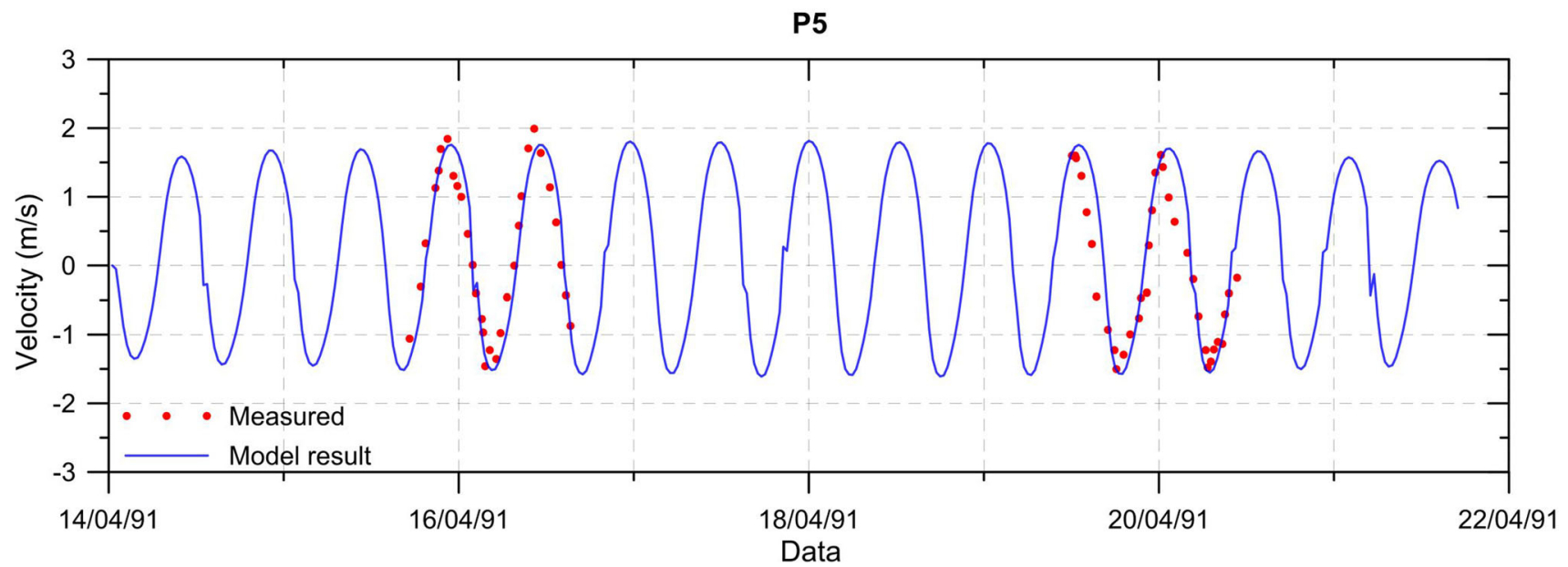

Fig. 4 Comparison between measured and computed current velocities at Area Delta-VI

where $C_{\mathrm{T}}$ represents the thrust coefficient, which is related to the power coefficient, $C_{\mathrm{P}}$, through the linear momentum actuator disk theory in an open channel developed by Houlsby et al. (2008), and based on the work of Rankine (1865) and Froude (1889):

$$
\begin{aligned}
& C_{\mathrm{T}}=\beta_{4}^{2}-\alpha_{4}^{2}, \\
& C_{\mathrm{P}}=\alpha_{2}\left(\beta_{4}^{2}-\alpha_{4}^{2}\right),
\end{aligned}
$$

where $\beta_{4}$ depicts for the bypass flow velocity coefficient, $\alpha_{2}$ is the turbine flow velocity coefficient, and $\alpha_{4}$ is the turbine 


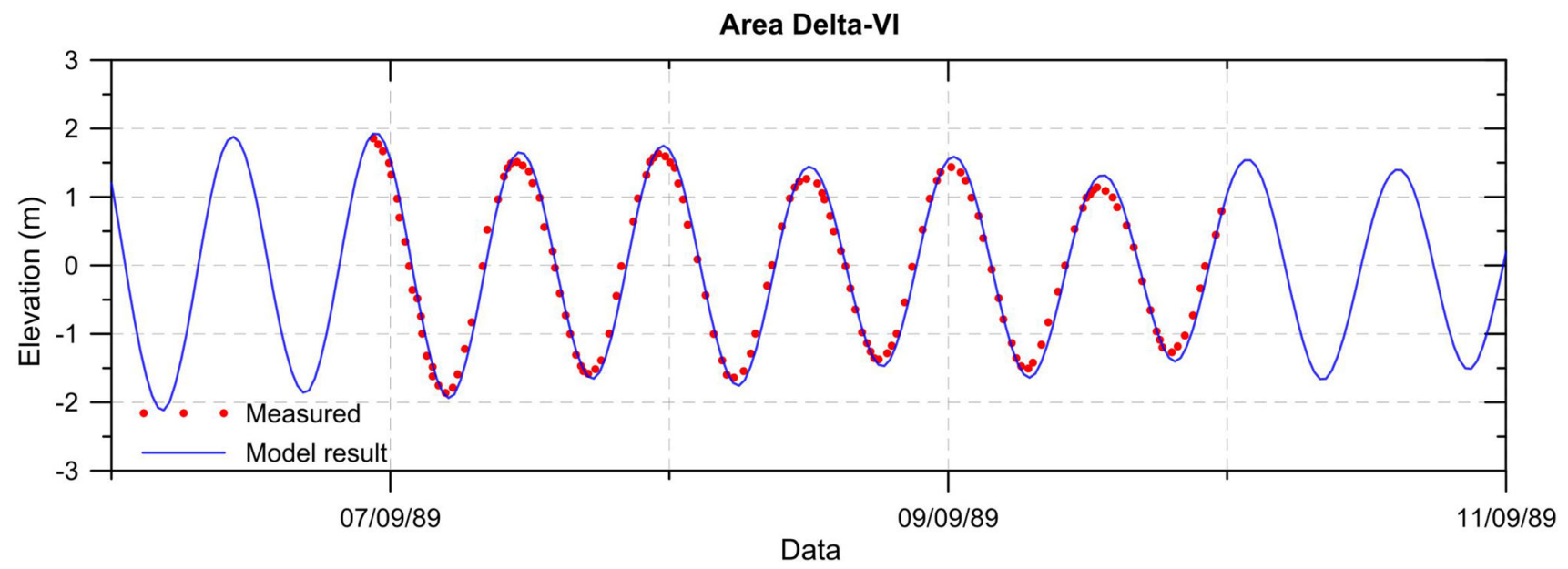

Fig. 5 Comparison between measured and computed water surface elevation (without mean water level) at Area Delta-VI

\section{Area Delta-VI}

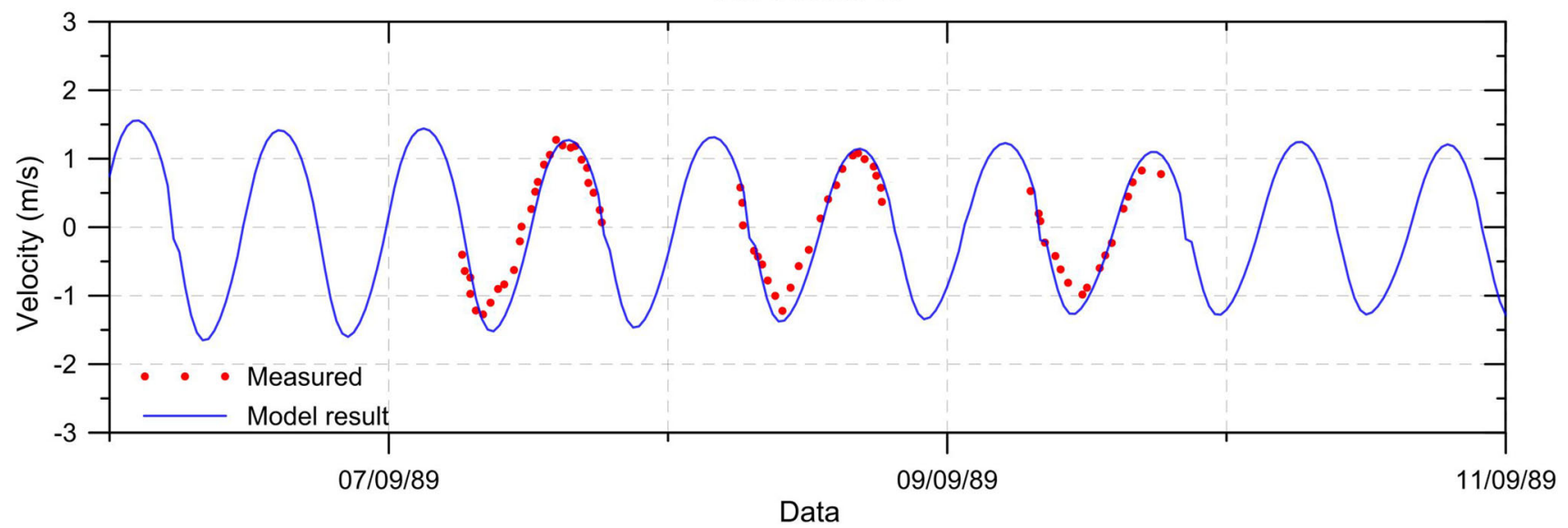

Fig. 6 Comparison between measured and computed current velocities at Area Delta-VI

wake flow velocity coefficient. According to the LanchesterBetz limit (Lanchester 1915; Betz 1920) for turbines in an infinite medium, i.e., no blockage, the optimal values are $\beta_{4}=1, \alpha_{2}=2 / 3$ and $\alpha_{4}=1 / 3$ corresponding to the values $C_{\mathrm{T}}=8 / 9$ and $C_{\mathrm{P}}=16 / 27$. Although tidal turbines within a farm positioned in constrained flows can result in this limit $\left(C_{\mathrm{P}}>16 / 27\right)$ being exceeded, a series of requirements have to be satisfied (Vennell 2013).

If $A_{\mathrm{T}}$ is the swept area of a TEC, $A_{\mathrm{I}}$ is the area of influence of each computational node, and $N_{\mathrm{T}}$ is the number of turbines per computational node, then

$\Theta=N_{\mathrm{T}}\left(A_{\mathrm{T}} / A_{\mathrm{I}}\right)$

which represents the total swept area per computational node, is known as nodal blockage.

Then the power available for a TEC is

$P=\frac{1}{2} \rho C_{\mathrm{P}} A_{\mathrm{T}} U^{3}$, where $U$ represents the flow velocity incident to each particular TEC. For the axial flow TEC type, $C_{\mathrm{T}}$ values vary with tip speed ratio (Bahaj et al. 2007), and as a result during a tide cycle values of $C_{\mathrm{T}}$ will be lower or higher than $C_{\mathrm{T}}$ for rated power. The same behaviour holds for $C_{\mathrm{P}}$. During operation, $C_{\mathrm{P}}$ values will reach a maximum corresponding to the optimal tip speed ratio. At the present time, a commercial scale axial flow pitch control TEC type, already tested, has a $C_{\mathrm{P}}$ in the range of $0.45-0.52$ (Fraenkel 2011) and a maximum of $C_{\mathrm{T}} \sim 0.82$ for a rated velocity of $2.4 \mathrm{~m} / \mathrm{s}$ (Fraenkel 2010). In order to estimate the power output generated by a tidal current turbine, the reader must be aware that due to effects of blockage and boundary proximity flow velocities incident to each TEC, $U$ may be different to the free stream velocity, $U_{o}$, used to calculate available power density.

\subsection{Hydrodynamic model setup}

In order to setup and run the hydrodynamic model, various input data sets are needed, which include bathymetric data, 
Fig. 7 Hot spots for efficient tidal current power extraction in São Marcos Bay. Zoom region shows bathymetry contours

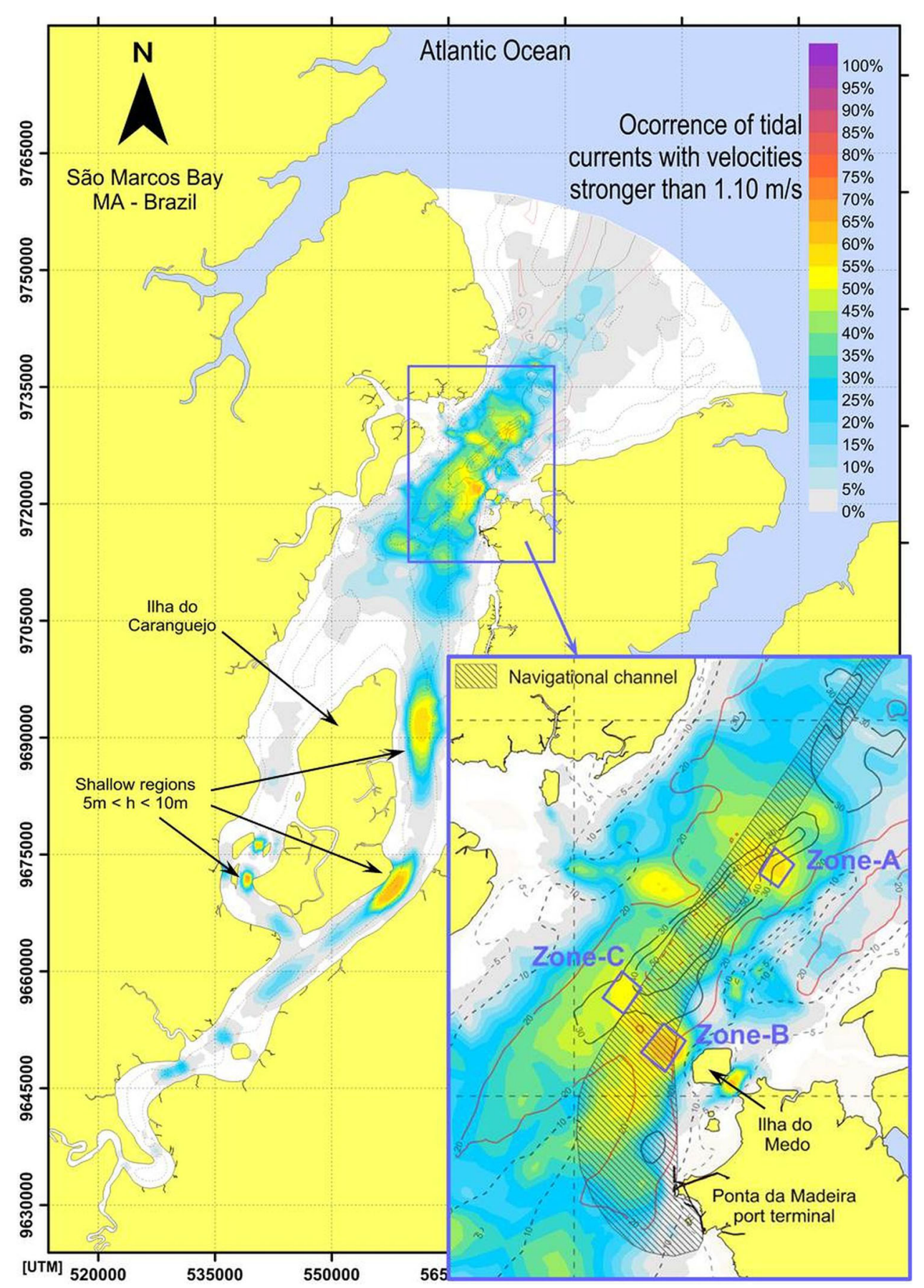

\begin{tabular}{lllllll}
\hline Zone & Width $(\mathrm{m})$ & Length $(\mathrm{m})$ & Depth $(\mathrm{m})$ & $U_{\text {avg }} \pm \mathrm{SD}(\mathrm{m} / \mathrm{s})$ & $U_{50}(\mathrm{~m} / \mathrm{s})$ & $U_{\text {Max }}(\mathrm{m} / \mathrm{s})$ \\
\hline A & 1000 & 1350 & $25-40$ & $1.10 \pm 0.06$ & 1.20 & 2.63 \\
B & 2600 & 1900 & 22 & $1.10 \pm 0.13$ & 1.23 & 2.42 \\
C & 1000 & 1100 & $30-35$ & $1.10 \pm 0.04$ & 1.12 & 2.19 \\
\hline
\end{tabular}

Table 3 Hydraulic/ hydrodynamic characteristics of zones with tidal energy potential main river discharges, and tides. Terrain modelling is done by digitising nautical charts for São Marcos Bay (Marinha do Brasil 1999a, b, c, d, 2000). Then, the domain has been discretised using a biquadratic finite element mesh, using 1244 elements with a total of 5757 calculation nodes. Figure 2 illustrates a portion of the computational grid used. 


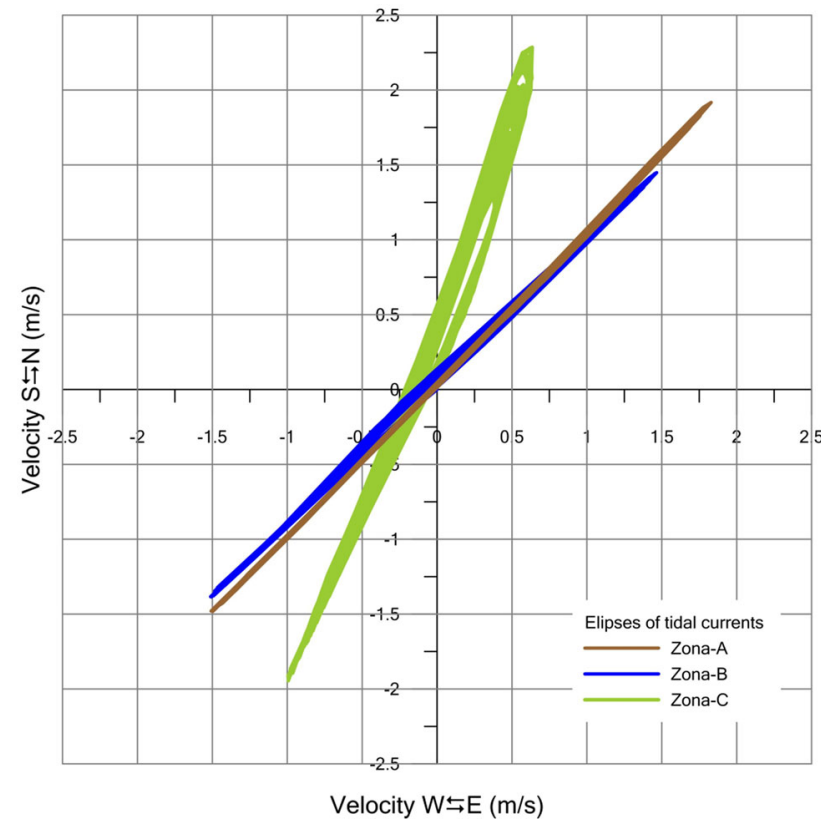

Fig. 8 Ellipses of tidal currents at zones A, B, and C indicated in the map of Fig. 7. Ebb currents are positive and flood currents are negative

Table 1 presents minimum and maximum monthly average discharges observed, during the period from 1964 to 1983, in hydrographic stations located in the three main rivers, Mearim, Pindaré e Grajaú, that flow into São Marcos Bay (Montes 1997).

From all established estuarine mixing criteria, e.g. Geyer and MacCready (2014) and Dyer (1998), one can verify that São Marcos Bay fits into the well-mixed type, and, therefore, baroclinic effects are of minor relevance. In fact for a mean tidal range reaching over $6 \mathrm{~m}$ in spring tides, only in rainy periods rivers' inflow have relevant effects, and, as stated in Malheiro da Silva (2011), riverine influence is restricted to the southern region of the estuary, almost $80 \mathrm{~km}$ away of the region of interest. This is the reason why for São Marcos Bay 2DH modelling, the main forcing factor taken into account in the model is the tide. Table 2 shows the amplitude and phase for the tidal constituents observed at the tidal gauge located at Ponta da Madeira, the main port of the region, and available in Salles et al. (2000).

\section{Results and discussion}

In this section the model calibration and results obtained of the hydrodynamic modelling are discussed, as well as the identification of zones for energy exploration and assessment of TEC array interferences.

\subsection{Numerical model validation}

The Brazilian National Institute of Waterways Research (INPH) has conducted several measurement campaigns in
São Marcos Bay (INPH 1991). Elevation and velocity current time series, presented in Dalbone (2014), are used to validate the hydrodynamic model. For this purpose, the principal tidal constituent of each family, $i=\mathrm{O} 1, \mathrm{M} 2, \mathrm{M} 3, \mathrm{M} 4$, measured at Ponta da Madeira's Port terminal shown in Table 2 , is individually propagated from the model outer boundary and adequately calibrated via two correction factors, $w_{A, i}$ and $w_{\varphi, i}$, applied to the constituent amplitude, $A_{i}$, and phase, $\varphi_{i}$, i.e. $w_{A, i} A_{i,}, w_{\varphi, i} \varphi_{i}$. Then, each correction factor has been applied for the rest of the family constituents and adopted as the main forcing factor in the model using Eq. (9):

$\zeta\left(\phi, \lambda, t_{i}\right)=\sum_{j=1}^{m} w_{A, j} A_{j}(\phi, \lambda) \cos \left[\omega_{j} t_{i}-w_{\varphi, j} \varphi_{j}(\phi, \lambda)\right]$

where $\zeta$ depicts the water surface level observed at time $t_{i}$, $\phi$ and $\lambda$ are East longitude and latitude, respectively, and $\omega_{j}$ represents the frequency of the $j$-th tidal constituent of a set with size $m$.

The validation is such that model results yield elevation and current velocity series similar to those measured at points named P5 and VI Area-Delta, whose locations are shown in Fig. 2. Comparison of computed and measured water surface elevation and velocity current is shown in Figs. 3, 4, 5 and 6. As can be seen therein, the correlation between computed and measured series possesses reasonable agreement. Differences in maximum current velocities may be attributed to differences in local bathymetry and the lack of wind field data.

\subsection{Prevailing hydrodynamic conditions at São Marcos Bay}

In accordance with the constraints described in Sect. 4, a map showing the percentage of occurrences of tidal currents velocities stronger than $1.1 \mathrm{~m} / \mathrm{s}$ for a 31-day period is plotted. From Fig. 7, it is visible that there are several interesting zones for power harnessing within São Marcos Bay. Three zones are identified as promising, referred to as zones A, B, and C. For Zone A, only the area located outside the waterway that gives access to Port facilities has been considered. This zone has tidal currents with velocities higher than $1.1 \mathrm{~m} / \mathrm{s}, 55$ $60 \%$ of the time, and lies in 25-40 m water depths. Zone B, with uniform depth of $22 \mathrm{~m}$, has the highest percentage of the three zones, with $60-65 \%$ of the time; however, it is inconveniently located within the navigation channel. Finally, zone $\mathrm{C}$ has the lowest velocity occurrences with $50-55 \%$ of the time and has water depths in the range of $30-35 \mathrm{~m}$. Table 3 summarises details for each zone. Other areas close to the above identified zones, as well as spots from the southern 

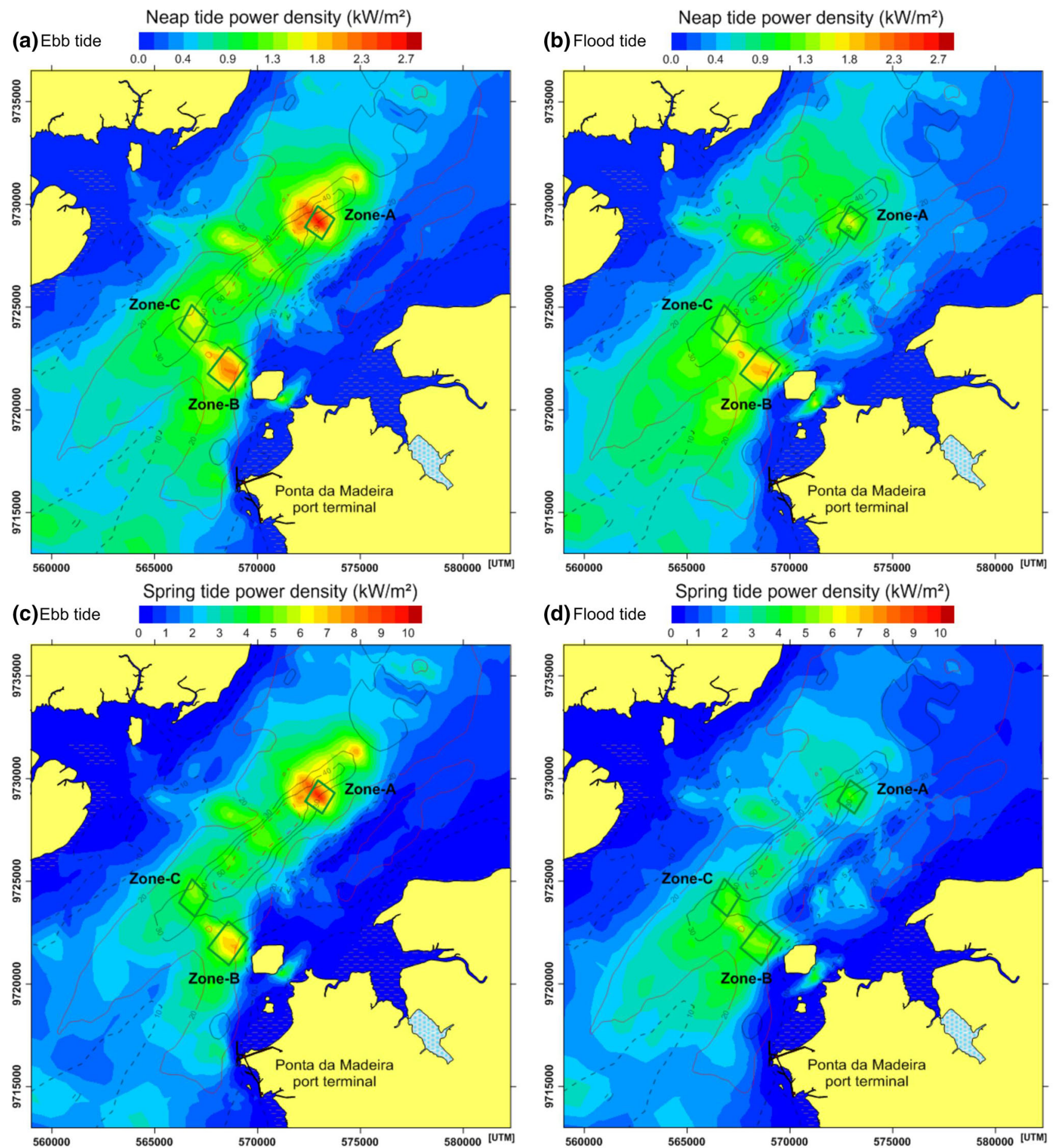

Fig. 9 Peak power density for a mean neap (top) and mean spring (bottom) tides

half of the bay, have been discarded due to low water depths, $\mathrm{h}<20 \mathrm{~m}$.

Tidal current ellipses have also been evaluated. Figure 8 shows ellipses for zones A, B, and C. Note that in all sites the currents have a well-defined principal axis, which is optimal for proper operational conditions of turbine arrays.

\subsection{Power density estimation and array interference}

By using Eq. (1) and the averaged vertical velocity magnitude for each zone, power density is calculated considering a sea water density of $1025 \mathrm{~kg} / \mathrm{m}^{3}$. For mid ebb and mid flood tides, Fig. 9 illustrates peak power density contour maps for mean 

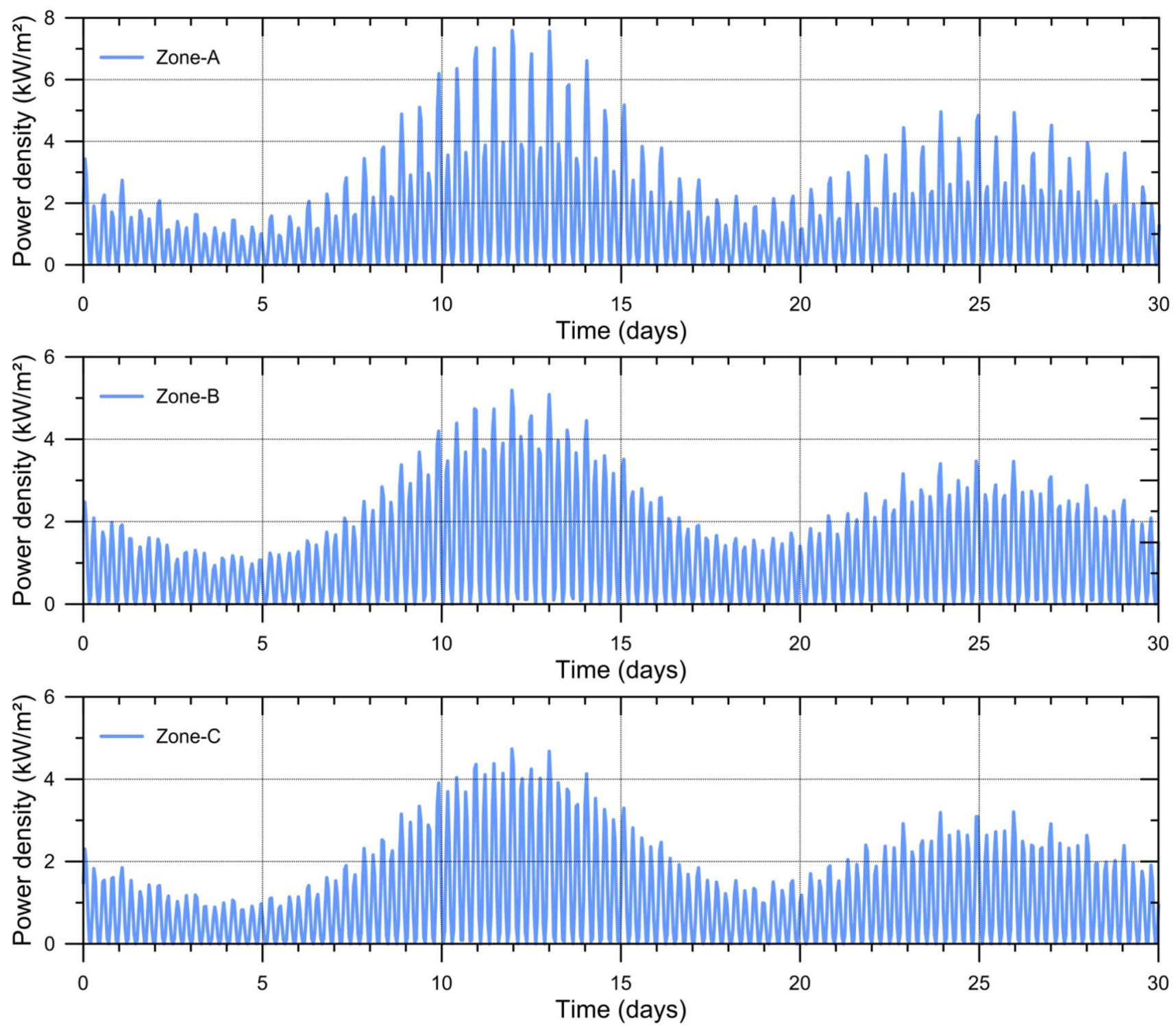

Fig. 10 Power density series for zones A, B, and C

Table 4 Power density summary for selected zones

\begin{tabular}{llll}
\hline Zone & \multicolumn{2}{l}{ Peak power $\left(\mathrm{kW} / \mathrm{m}^{2}\right)$} & $\begin{array}{l}\text { Avg. annual power } \\
\text { density }\left(\mathrm{MWh} / \mathrm{m}^{2}-\right. \\
\text { year })\end{array}$ \\
\cline { 2 - 3 } & Spring tide & Neap tide & 11.2 \\
\hline A & 7.5 & 2.1 & 10.4 \\
B & 5.1 & 1.5 & 9.2 \\
C & 4.8 & 1.5 & \\
\hline
\end{tabular}

neap and mean spring tides. Then, average power density series for zones A, B, and C have been computed for a 30-day period and presented in Fig. 10. These graphs show that significant amounts of power can be extracted from tidal currents at São Marcos Bay. Also, from the graphs, it is noticeable that the difference in power density magnitude between flood and ebb tides, particularly for Zone-A, is almost doubled during the outgoing tide. By integrating the power series, the amount of power density annually available has been calculated at each selected zone. Results, summarised in Table 4, indicate peak power densities during a mean spring tide of up to 7.5, 5.1 , and $4.8 \mathrm{~kW} / \mathrm{m}^{2}$ for zones $\mathrm{A}, \mathrm{B}$, and $\mathrm{C}$, respectively, while for mean neap tide, power densities have been found to be in the range of $1.5-2.1 \mathrm{~kW} / \mathrm{m}^{2}$. Results for annual average power densities are close, lying between $11.2 \mathrm{MWh} / \mathrm{m}^{2}$ for zone $\mathrm{A}$ and $9.2 \mathrm{MWh} / \mathrm{m}^{2}$ for zone $\mathrm{C}$.

Once power densities have been calculated for each zone, it is of interest to evaluate hydrodynamic interferences between individual TEC arrays in the remaining zones. For this purpose, the $2 \mathrm{DH}$ hydrodynamic model is re-run con- 
Table 5 Per cent of power density gain (+) or loss (-) due to array interference

\begin{tabular}{|c|c|c|c|c|c|c|c|}
\hline \multirow[t]{2}{*}{ TEC density } & \multirow{2}{*}{$\begin{array}{l}\text { Zone } \\
\text { affected }\end{array}$} & \multicolumn{3}{|c|}{ Array location, $C_{\mathrm{T}}=0.54$} & \multicolumn{3}{|c|}{ Array location, $C_{\mathrm{T}}=0.82$} \\
\hline & & $\mathrm{A}(\%)$ & $\mathrm{B}(\%)$ & $\mathrm{C}(\%)$ & $\mathrm{A}(\%)$ & $\mathrm{B}(\%)$ & $\mathrm{C}(\%)$ \\
\hline \multirow[t]{3}{*}{$1 \mathrm{TEC} / 25,000 \mathrm{~m}^{2}$} & A & - & -7 & -7 & - & -11 & -9 \\
\hline & $\mathrm{B}$ & -13 & - & -3 & -13 & - & 1 \\
\hline & $\mathrm{C}$ & -6 & 26 & - & -7 & 27 & - \\
\hline \multirow[t]{3}{*}{$1 \mathrm{TEC} / 15,000 \mathrm{~m}^{2}$} & $\mathrm{~A}$ & - & -11 & -9 & - & -12 & -10 \\
\hline & B & -13 & - & 1 & -15 & - & 6 \\
\hline & $\mathrm{C}$ & -7 & 29 & - & -8 & 36 & - \\
\hline \multirow[t]{3}{*}{$1 \mathrm{TEC} / 5000 \mathrm{~m}^{2}$} & A & - & -14 & -13 & - & -14 & -14 \\
\hline & $\mathrm{B}$ & -15 & - & 13 & -15 & - & 20 \\
\hline & $\mathrm{C}$ & -9 & 52 & - & -9 & 59 & - \\
\hline
\end{tabular}

sidering different TEC density scenarios. In particular, three TEC densities are studied for each zone: 1 TEC every 25,000, 15,000 , and $5000 \mathrm{~m}^{2}$. Considering the constraints for efficient power extraction cited in Sect. 4 , the simulations are run using an $A_{\mathrm{T}}=\pi 10^{2} \mathrm{~m}^{2}$ for zones $\mathrm{A}$ and $\mathrm{C}$, and $A_{\mathrm{T}}=\pi$ $7.5^{2} \mathrm{~m}^{2}$ for zone B. These turbine swept areas correspond to horizontal axis turbines with rotor diameters of $20 \mathrm{~m}$ and $15 \mathrm{~m}$, respectively. Uniform value of $C_{\mathrm{T}}=0.54$ and $C_{\mathrm{T}}=0.82$ have been selected based on Fraenkel (2010) for median flow velocity $(\sim 1.2 \mathrm{~m} / \mathrm{s})$ and nominal flow velocity $(2.4 \mathrm{~m} / \mathrm{s})$, respectively. The stress term effect associated with the presence of turbines is homogenously distributed throughout each zone. Then, the results from the simulations are used to compute new annual power densities and are compared with previous ones. Table 5 summarises the percentage in power density gain or loss along a year for each zone due to TEC array density interference for both thrust coefficients.

As can be seen, array interference in adjacent promising sites are not irrelevant. On the one hand, TEC arrays placed in zone $\mathrm{B}$ or $\mathrm{C}$ have adverse effects on annual power density of zone A, and vice versa, whilst on the other hand, arrays in B and C cause energy density gains between each other. Adverse effects do not exceed $15 \%$ losses in any of the modelled scenarios. The benefits in power density are more evident when TECs are positioned in zone B, attaining a gain in $\mathrm{C}$ that intensifies from $26 \%$ up to $52 \%$, as turbine density increases. In general, simulations run with a higher $C_{\mathrm{T}}$ intensified its effects. In some cases, prediction of hydrodynamic effects are not so intuitive. Such is the case of zone $C$ for simulations with $C_{\mathrm{T}}=0.54$, when low turbine densities are placed in this area generate negative impacts in zone B, but increasing the number of turbines leads to in an increase in power density.

The sizes of the elements with respect to the size of the turbines have been defined considering an affordable computational cost. As the mesh is refined, the same total drag force would not change, as it would be distributed over a larger number of nodes. However, for a finer mesh one could expect some differences in the near wake of TEC arrays, as smaller eddies could be resolved, due to the fact that the turbulence model depends on the local mesh scale, see (Rosman 1987).

\section{Conclusions}

The hydrodynamic model has indicated several zones with occurrence of tidal median current velocities greater than 1.1 $\mathrm{m} / \mathrm{s}$ over $50 \%$ of the time during a lunar month. Zones with depths lower than $20 \mathrm{~m}$ have been discarded, leaving three zones named A, B, and C. These zones are within, zone B, or in the vicinities of, zone $\mathrm{A}$ and $\mathrm{C}$, the main waterway that gives access to terminal Port facilities of the region. A preliminary estimate, for these areas, shows large amounts of energy available at São Marcos Bay with annual power densities ranging from 9.2 to $11.2 \mathrm{MWh} / \mathrm{m}^{2}$. However, having in mind the assumptions considered in this study, particular care must be taken when interpreting these estimates. As new technologies evolve, energy extraction from shallow regions of the Bay will be feasible, increasing considerably the amounts of power production.

The maximum available power for electric energy generation from São Marcos Bay will depend on both the array packing density at each zone and their individual influences over hydrodynamics on the remaining selected zones. Positive or negative interferences are mainly due to blockage, which modifies the tidal flow path. These complex flowturbine farms interactions may be considered as evidence for the necessity of complex layout optimisation procedures, like those proposed by Funke et al. (2014) and Gorbeña et al. (2015), in order to prevent adverse effects between TEC arrays, as well as to maximise power production. As recommendations for futures works, hydro-sediment modelling and simulations with thrust coefficients dependant on flow velocity, $C_{\mathrm{T}}(U)$, are desired so to improve the quantification 
of interferences on tidal stream and shear stresses related to turbine arrays. Finally, the maximum amount of extractable power for the whole Bay is dependent upon a range of other factors such as those arising from environmental and socioeconomic issues.

Acknowledgments The authors wish to acknowledge the financial support provided by the Inter-American Development Bank, without which this work would not have been possible. The corresponding author wishes to acknowledge the Ph.D. scholarship provided by the following funding agencies: Federal Agency for Support and Evaluation of Graduate Education of Brazil (CAPES) and the Foundation for Supporting Research in the State of Rio de Janeiro (FAPERJ).

\section{References}

Adcock TAA, Draper S (2014) Different metrics for estimating the tidal stream energy resource, 1 st PRiMaRE conference. Plymouth, UK

Adcock TAA, Draper S, Houlsby GT, Borthwick AGL, Serhadlıŏlu S (2013) The available power from tidal stream turbines in the Pentland Firth. Proc R Soc Lond A 469(2157):20130072. doi:10. 1098/rspa.2013.0072

Allan G, Gilmartin M, McGregor P, Swales K (2011) Levelised costs of wave and tidal energy in the UK: cost competitveness and the importance of "banded" renewables obligation Certificates. Energ Policy 39:23-30. doi:10.1016/j.enpol.2010.08.029

Bahaj AS, Batten WMJ, McCann G (2007) Experimental verifications of numerical predictions for the hydrodynamic performance of horizontal axis marine current turbines. Renew Energ 32:24792490. doi:10.1016/j.renene.2007.10.001

Betz A (1920) Das Maximum der theoretisch moglichen Ausnutzung des Windes durch Windmotoren. Zeitschrift für das gesamte Turbinenwesen 26:307-309

Blunden LS, Bahaj AS, Aziz NS (2013) Tidal current energy for Indonesia? An initial resource estimate for the Alas Strait. Renew Sust Energ Rev 49:137-142. doi:10.1016/j.renene.2012.01.046

Brooks DA (2011) The hydrokinetic power resource in a tidal estuary: the Kennebec River at the central Marine coast. Renew Energ 36:1492-1501. doi:10.1016/j.renene.2010.10.029

Bryden IG, Couch SJ (2007) How much energy can be extracted from moving water with a free surface: a question of importance in the field of tidal current energy? Renew Energ 32:1961-1966. doi:10. 1016/j.renene.2006.11.006

Bryden IG, Couch SJ, Owen A, Melville G (2007) Tidal current resource assessment. Proc IMechE Part A 221(2):125-135. doi:10.1243/ 09576509JPE238

Chen W-B, Liu W-C, Hsu M-H (2013) Modeling assessment of tidal current energy at Kinmen Island, Taiwan. Renew Energ 50:10731082. doi:10.1016/j.renene.2012.08.080

Dalbone RC (2014) Análise das Assimetrias de Correntes de Maré ao Longo do Canal de Acesso Portuário de Baía de São Marcos: Estuário de Macromarés. M.Sc. Dissertation, Ocean Eng Dep; COPPE, Universidade Federal do Rio de Janeiro (In portuguese)

Define Z, Haas KA, Fritz HM (2011) Numerical modeling of tidal currents and the effects of power extraction on estuarine hydrodynamics along the Georgia coast, USA. Renew Energ 36:3461-3471. doi:10.1016/j.renene.2011.05.027

Denny E (2009) The economics of tidal energy. Energ Policy 37:19141924. doi:10.1016/j.enpol.2009.01.009

Dyer KR (1998) Estuaries: a physical introduction, 2nd edn. Wiley, New York
El-Robrini M, Marques VJ, Silva MA, El-Robrini MHS, Feitosa A, Tarouco JEF, Santos JHS, Viana JR (2006) Atlas de erosão e progradação da zona costeira do estado do maranhão - região amazônica: área oceânica e estuarina, Dieter Muehe. (Org.). Atlas de erosão e progradação da zona costeira brasileira, São Paulo, pp 1-44

Fraenkel PL (2002) Power from marine currents. Proc IMechE 216 Part A J Power Energ, 1-14: doi:10.1243/095765002760024782

Fraenkel PL (2007) Marine current turbines: pioneering tidal stream technology. Proc. IMechE 221, Part A J Power Energ, 159-169: doi:10.1243/09576509JPE307

Fraenkel PL (2010) Development and testing of Marine Current Turbine's SeaGen 1.2 MW tidal stream turbine. In: $3^{\text {rd }}$ int conf ocean ener, 6 Oct, Bilbão

Fraenkel PL (2011) MCT's SeaGen tidal turbine. Short presentation

Froude RE (1889) On the part played in propulsion by differences of fluid pressure. Trans R Inst Naval Archit 30:390-405

Funke SW, Farrell PE, Piggott MD (2014) Tidal turbine array optimisation using the adjoint approach. Renew Energ 63:658-673. doi:10. 1016/j.renene.2013.09.031

Garrett C, Cummins P (2008) Limits to tidal current power. Renew Energ 33:2485-2490. doi:10.1016/j.renene.2008.02.009

Geyer WR, MacCready P (2014) The estuarine circulation. Annu Rev Fluid Mech 46(1):175

Gorbeña EG, Qassim RY, Rosman PCC (2015) A metamodel simulation based optimisation approach for the tidal turbine location problem. Aquat Sci Tech 3(1):33-58. doi:10.5296/ast.v3i1.6544

Grabble M, Lalander E, Lundin S, Leijon M (2009) A review of the tidal current energy resource in Norway. Renew Sust Energ Rev 13:1898-1909. doi:10.1016/j.rser.2009.01.026

Hardisty J (2009) The analysis of tidal stream power. Wiley-Blackwell, UK

Houlsby GT, Draper S, Oldfield M (2008) Application of linear momentum actuator disc theory to open channel flow. Tech rep no 2296-08, University of Oxford, Oxford, UK

INPH (1991) Relatório das medições hidráulicas realizadas na Baia de São Marcos MA, INPH 54/91. Baia de São Marcos 700(01):45

Kammen DM, Pacca S (2004) Assessing the costs of electricity. Annu Rev Env Res 29301-29344: doi:10.1146/annurev.energy.28. 050302.105630

Lanchester FW (1915) A contribution to the theory of propulsion and the screw propeller. Trans R Inst Naval Archit 57:98-116

Li Y, Lence BJ, Calisal SM (2011) An integrated model for estimating energy cost of a tidal current turbine far. Energ Convers Manage 52:1677-1687. doi:10.1016/j.enconman.2010.10.031

Lim YS, Koh SL (2010) Analytical assessments on the potential of harnessing tidal currents for electricity generation in Malaysia. Renew Energ 35:1024-1032. doi:10.1016/j.renene.2009.10.016

Liu H-W, Ma S, Li W, Gu H-G, Sun X-S (2011) A review of the development of tidal current energy in China. Renew Sust Energ Rev 15:1141-1146. doi:10.1016/j.rser.2010.11.042

Malheiro da Silva R (2011) Técnica de interferometria SAR e modelagem hidrodinâmica para avaliação de locais adequados ao aproveitamento da energia das correntes de maré. $\mathrm{PhD}$ Thesis, Ocean Eng Dep; COPPE-Universidade Federal do Rio de Janeiro

Marine Current Turbines (2012) Tidal energy. Retrieved 2015, from Marine Current Turbines. http://www.marineturbines.com/ Tidal-Energy

Marinha do Brasil (1999a) Carta Náutica 410: Proximidades da Baía de São Marcos. Escala: 1:50.000

Marinha do Brasil (1999b) Carta Náutica 411: Baía de São Marcos. Escala: 1:50.000

Marinha do Brasil (1999c) Carta Náutica 412: Baía de São Marcos proximidades do Terminal da Ponta da Madeira e Itaqui. Escala: 1:50.000 
Marinha do Brasil (1999d) Carta Náutica 413: Terminal da Ponta da Madeira e Itaqui. Escala: 1:50.000

Marinha do Brasil (2000) Carta Náutica 414: Baía de São Marcos de Itaqui ao Terminal Alumar. Escala: 1:50.000

Montes ML (1997) Zoneamento Geoambiental do Estado do Maranhão, In: Diretrizes gerais para a ordenação territorial, IBGE, Salvador, BA, Brasil

Myers L, Bahaj AS (2005) Simulated electrical power potential harnessed by marine current turbine arrays in the Alderney Race. Renew Energ 30:1713-1731. doi:10.1016/j.renene.2005.02.008

Pereira MG, Camacho CF, Freitas MAV, da Silva NF (2012) The renewable energy market in brazil: current status and potential. Renew Sust Energ Rev 16:3786-3802. doi:10.1016/j.rser.2012.03.024

Qassim RY (2011) Optimisation of systems for the extraction of energy from tidal currents, Inter-American Development Bank Contract ATN/MC-11513-RG. COPPETEC Foundation, Rio de Janeiro

Rankine WJM (1865) On the mechanical principles of the action of propellers. Trans R Inst Naval Archit 6:13

Rashid A (2012) Status and potentials of tidal in-stream energy resources in the southern coasts of Iran: a case study. Renew Sust Energ Rev 16:6668-6677. doi:10.1016/j.rser.2012.08.010

Rosman PCC (1987) Modelling shallow water bodies via filtering techniques. $\mathrm{PhD}$ thesis, Massachusetts Institute of Technology
Rosman PCC (2009) Analyses of the effects of turbine array densities in the tidal currents in São Marcos Bay-MA-Technical Report in project Selecting sites for tidal current power extraction in Brazil, Fundação Coppetec, PENO11297 (In Portuguese)

Rosman PCC (ed) (2014) Referência Tecnica SisBaHiA. COPPE - Universidade Federal do Rio de Janeiro (In Portuguese). http://www. sisbahia.coppe.ufrj.br/SisBAHIA_RefTec_V95.pdf

Rourke FO, Boyle F, Reynolds A (2010) Marine current energy devices: current status and possible future trends in Ireland. Renew Sust Energ Rev 14:1026-1036. doi:10.1016/j.rser.2009.11.012

Salles FJP, Bentes FCM, Santos JA (2000) Catalogo de Estacoes Maregráficas Brasileiras, Fundação de Estudos do Mar - FEMAR, first ed., Rio de Janeiro

Thomson MD (2011) Whelan JI, Gill L, The development of a tool for the design and optimisation of tidal stream turbine arrays. In: Proc 9th Eur wave tidal energ conf, Southampton, UK

Vennell R (2012a) Realizing the potential of tidal currents and the efficiency of turbine farms in a channel. Renew Energ 47:95-102. doi:10.1016/j.renene.2012.03.036

Vennell R (2012b) The energetics of large tidal turbine arrays. Renew Energ 48:210-219. doi:10.1016/j.renene.2012.04.018

Vennell R (2013) Exceeding the Betz limit with tidal turbines. Renew Energ 55:277-285. doi:10.1016/j.renene.2012.12.016 